\title{
Reciprocal Teaching Strategies and Their Impacts on English Reading Comprehension
}

\author{
Mohammad Reza Ahmadi \\ School of Educational Studies, Universiti Sains Malaysia, Malaysia \\ Email:mr.ahmadi2720@yahoo.com \\ Abbas Pourhossein Gilakjani \\ Islamic Azad University of Lahijan, Iran \\ Email: abbas.pouhossein@yahoo.com
}

\begin{abstract}
Whenever teachers are faced with the problem of students who do not have adequate comprehension skills, they need to be able to train those students to use metacognitive strategies; otherwise, these students will continue to read texts emphasizing only words and not meaning. One set of metacognitive strategies are the reciprocal teaching strategies used to improve students' reading comprehension. Reciprocal teaching involves four main metacognitive reading strategies: predicting, questioning, clarifying, and summarizing. The aims of this paper are to define the key terms, explain the models of reading process, review reading process and reading strategies, discuss cognitive and metacognitive strategies and reading comprehension, elaborate reciprocal teaching and its theoretical framework, mention the related research on reciprocal teaching, and state relationship between reciprocal teaching and reading comprehension. The findings indicated that reciprocal teaching had a significantly positive effect on the English reading comprehension and usage of the four main metacognitive reading strategies of EFL students.
\end{abstract}

Index Terms-reciprocal teaching, reading comprehension, cognitive strategies, metacognitive strategies, models

\section{INTRODUCTION}

To communicate efficiently, learners need the four skills of listening, speaking, reading, and writing, but of all these four skills, reading is regarded as the most vital and necessary for students in both a classroom context and an extracurricular environment (Carrell, 1989; Grabe \& Stoller, 2002). Reading is even more important for high-school students since they have to be highly competitive in the English entrance examination. Therefore, the ability to read an comprehend texts efficiently is crucial for EFL students. In addition, because of the demanding expectations for academic success in all areas of learning, high-school students, as English foreign language (EFL) learners, need to develop their English reading comprehension abilities to a stronger, more advanced level (Soonthornmanee, 2002).

Although every student knows how to read, many have never learned good reading skills (Royse, 2001). This lack of good reading skills is exacerbated by the central role of reading comprehension in higher education success. According to Hart and Speece (1998), "one of the greatest demands on students attending post-secondary institutions is the comprehension of many different and difficult texts" (p. 670). One solution to this problem of poor reading comprehension skills is the explicit teaching of reading comprehension strategies to both undergraduate and graduate students (e.g., reciprocal teaching, SQ4R, induced imagery). Explicit instruction in reading comprehension strategies is an effective means for improving reading comprehension in adults. Unfortunately, explicit instruction in reading comprehension is rarely taught at the higher education level (Wilson, 1988; Pressley, Woloshyn, Lysynchuk, Martin, Wood, \& Willoughby, 1990). In this paper, the researchers discuss the key terms, the models of reading process, reading process and reading strategies, cognitive and metacognitive strategies and reading comprehension, reciprocal teaching and its theoretical framework, the related research on reciprocal teaching, and relationship between reciprocal teaching and reading comprehension.

\section{Definition OF KeY TERMS}

\section{A. Reciprocal Teaching}

Reciprocal teaching has been defined in many different ways. According to Rosenshine and Meister (1994), reciprocal teaching is an instructional strategy that directly teaches students to apply metacognitive thinking as they make meaning from a text. According to Carter (1997), reciprocal teaching parallels the new definition of reading that describes the process of reading as an interactive one, in which readers interact with the text as their prior experience is activated. Using prior experience as a channel, readers learn new information, main ideas and arguments. Most important, readers construct meaning from the text by relying on prior experience to parallel, contrast or affirm what the 
author suggests. All excellent readers do this construction. Otherwise, the content would be meaningless, alphabetic scribbles on the page. Without meaning construction, learning does not take place. Reciprocal teaching is a model of constructivist learning.

Klingner and Vaughn (1996, p. 275) reported the following definition of reciprocal teaching defined by Lysynchuck et al., (1990): "The reciprocal teaching model has been used to improve comprehension for students who can decode but have difficulty comprehending text." Palincsar and Brown (1984) added in an article reported by Hacker and Tenent (2002) "Reciprocal teaching is an instructional procedure in which small groups of students learn to improve their reading comprehension through scaffold instruction of comprehension-monitoring strategies" (p. 669). It consists of four main strategies: predicting, questioning, clarifying, and summarizing. It occurs in the form of dialogues between teachers and students. At first, the students learn the four key strategies and practice them. Second, the teacher models the entire process step by step using structured dialogues. Third, the teacher gives the students a chance to get involved and coaches them on how to ask appropriate questions, write adequate summaries, and so on. Gradually, the teacher's role as a leader decreases. Finally, the students take on greater responsibility to carry out the whole process.

From the definitions above, it can be concluded that reciprocal teaching is a scaffolded discussion method that is based on reading comprehension strategies, scaffolding and modeling, and social interaction. This instruction allows a teacher to model and give the students enough practice on those four main strategies to construct the meaning of a text in a social setting. The students monitor their own thinking through the reading process. Reciprocal teaching develops reading comprehension and promotes readers to be better in reading and helps them reach the most important goal of reciprocal teaching, becoming independent readers.

\section{B. Reading Comprehension}

Reading comprehension has been defined in many ways over the years. Nuttall (1996) suggests that the overriding purpose to reading is to get the correct message from a text - the message the writer intended for the reader to receive. Allen (2003) stated that the idea of reading has changed and moved from what was considered a receptive process to what is now an interactive process. Reading can be done using a number of processes that can be divided into two main categories: bottom-up processing and top-down processing. Bottom-up processing refers to the reader obtaining meaning from the letters and words of a text and reconstructing the intended message that way. Top-down processing refers to the reader's ability to look at a text as a whole and to connect and relate it to his existing knowledge base. Both processes are needed to obtain a message from a text.

\section{Reading Comprehension Strategies}

They refer to the conscious and flexible plan that students apply and adapt to a text when they face problems while reading. Readers use reading comprehension strategies, both cognitive and metacognitive, to better understand reading texts and in order to learn to read independently (Allen, 2003).

\section{Metacognitive Strategies}

They refer to the set of reading tactics through which learners are capable of becoming aware of their mental process. It involves thinking about the mental operation used in the learning process, monitoring or controlling learning while it is taking place, solving problems, and evaluating learning after it has occurred. The metacognitive strategies the learners may use when they read include: planning the task and content sequence; focusing on key words, phrases, and ideas; asking questions to clarify meaning; deciding which strategy to use to solve the reading problems; checking whether the predictions/guesses are correct; and evaluating their own progress and whether the goal is met (Oxford, 1990).

\section{MODELS OF READING PROCESS}

Reading is a cognitive process that consists of a reader, a text, and the interaction between the reader and the text. There are three models for the second-language reading process: the bottom-up model, the top-down model, and the interactive model.

\section{A. The Bottom-up Model}

This reading model focuses on the smaller units of a text such as its letters, words, phrases and sentences. Then, a syntactic and semantic processing occurs during which reading reaches the final meaning. In this model, the reader reads all of the words in a phrase, or a sentence before being able to understand. The bottom-up reading process begins with decoding the smallest linguistic units, especially phonemes, graphemes, and words, and ultimately constructs meaning from the smallest to the largest units. While doing this, the readers apply their background knowledge to the information they find in the texts. This bottom-up method is also called data-driven and text-based reading (Carrell, 1989). The disadvantage of this model is that the readers will only be successful in reading if they accurately decode the linguistic units and recognize the relationship between words. It is impossible for the readers to store in their memory the meaning of every word in a passage. It is also difficult to relate one word to the other words. It can be concluded that there are some arguments against the bottom-up model. In the reading process, the readers understand that what they have read is the result of their own constructions, not the result of the transmission of graphic symbols to their understanding, and that without their background knowledge, they cannot comprehend the texts. 


\section{B. The Top-down Model}

The top-down model was first introduced by Goodman (1967). He proposed the idea of reading as a "psycholinguistic guessing game" in which the reader uses his background (prior) knowledge or textual schemata to connect with a text and to relate these to new or unexpected information found in the text in order to understand it. This model focuses on linguistic guesswork rather than graphic textual information. The readers do not need to read every word of a text, but rather, they concentrate on predicting the next group of words. They concern themselves with guessing the meaning of the words or phrases. Readers might start predicting from the title of the reading text, something that allows them to limit the scope of their reading. While reading, they may hypothesize the message the writer wants to convey and modify their hypotheses according to what they read in the text. Comprehension begins with higher levels of processing (making hypotheses), and proceeds to the use of the lower levels (Nuttall, 1996).

\section{The Interactive Model}

This model is built on the interaction of the bottom-up and top-down models. Nunan (1990), Rumelhart (1977), and Grabe (1991) argue that efficient and effective reading requires both top-down and bottom-up decoding. L2 readers, for example, may use top-down reading to compensate for deficiencies in bottom-up reading. To achieve meaning, they use their schemata to compensate for the lack of bottom-up knowledge Stanovich (1980) argued that the interactive model is a process based on information from several sources such as orthographic, lexical, syntactic, semantic knowledge, and schemata. While reading, decoding processes can support one another in a compensatory way. If, when reading word by word, readers with good bottom-up skills do not comprehend the texts, they need to use their prior knowledge (schemata) to assist them. Readers who rely on the top-down model use textual clues and guess wildly at the meaning, but they need to compensate for deficits such as weaknesses in word recognition and lack of effective bottom-up processing. The interactive model, which is the combination of the bottom-up and top-down processes, leads to the most efficient processing of texts. Knowing that the interactive model can help L2 readers in achieving successful reading, teachers should find reading instructions based on this model to promote L2 readers' abilities. The reciprocal teaching approach is a type of reading instruction that is based on the interactive model. It covers four main reading strategies.

\section{ReAding Process AND ReAding Strategies}

There appears to be a consensus that reading is a highly complex cognitive process that involves the reader, the text, and the interaction between the reader and the text (Kern, 1989). In the reading process, the reader interacts with the text to construct meaning from it using various kinds of background knowledge: linguistic knowledge of words, sentences and paragraphs, and cognitive abilities (Carrell, 1989). Reading comprehension then involves a complex combination of the reader's cognitive process, language proficiency, and metacognitive processes (Cohen, 1998). The reader has to make inferences on the context of a text or on the end of a story by using information from various sources: the title, the illustrations, or generally from the previous paragraphs. Readers have to monitor their reading behavior and find out whether they understand the text (Grabe \& Stoller, 2002). When a text is difficult, the reader might reread it (parts of it or the whole of it), or he/she can ask questions about it (Paris, Cross \& Lipson, 1984). The reading comprehension processes occur when the reader understands the information in a text and appropriately and meaningfully interprets it (Grabe \& Stoller, 2002). Reading strategies are conscious and flexible plans that readers apply and adapt to a variety of texts. Reading strategies indicate how readers understand a task, what textual clues they attend to, how they make sense of what they have read, and what they do when they do not understand the reading texts. In order to help students to comprehend reading texts, it is necessary for the teachers to teach reading strategies in the English classrooms. That is, the teachers need to teach reading strategies with the proper steps (Graves, Connie, \& Bonnie, 1998). The effective reading process is divided into three stages: (a) pre-reading, (b) while-reading, and (c) post-reading. These steps of the reading process help students systematically practice reading strategies (Cohen, 1998).

To begin with, in pre-reading, the readers need to apply specific strategies, including scanning and guessing, to survey the type of text they are going to read and to recognize its difficulties. They then read the title, link it to their schemata, and predict the content. These strategies help them create a narrow picture of the text and check whether their prediction is right or wrong (Cohen, 1998; Mejang, 2004). In the while-reading stage, the learners also need strategies such as self-questioning, self-monitoring, and problem-solving (Allen, 2003; Cohen, 1998). Students should be trained in questioning skills so that they can ask themselves questions on the salient points of a text. For example, they can ask a question about the main idea, the supporting details, or the conclusion. Self-monitoring is a strategy that readers use to check their comprehension (Cohen, 1998; Allen, 2003). It is an ongoing activity which involves two components: evaluation and regulation (Wenden, 1999). Evaluation refers to the readers' realization of a comprehension failure and to their assessment of comprehension progress, whereas regulation relates to the strategies used to remedy any comprehension breakdown (Zabrucky \& Ratner, 1992). Cohen (1998) suggests the teacher should teach the useful strategies of summarizing, clarifying, rereading, and guessing so that the students possess a model of reading to solve the problems while reading. These strategies help the students find solutions to their difficulties when they are confronted with reading problems. Finally, in the post-reading stage, readers need to evaluate the strategies they used and the quality of their comprehension, and they need to respond to this self-evaluation by asking themselves what they 
try to do, how they plan to do it, and how well they can do it. All of these questions help them evaluate whether their course of action is effective or not (Alderson, 2000).

Less proficient readers with insufficient knowledge of cognitive strategies cannot make sense of a text they have read because they fail to control or monitor their own reading process (Baker \& Brown, 1984). Proficient readers, on the other hand, can apply appropriate cognitive reading strategies to facilitate their comprehension. They are also aware of their own reading process through which they apply regulatory mechanisms, the so-called metacognitive strategies proposed by Baker and Brown (1984), to control and monitor their reading behavior, in order to facilitate effectively the reading process (Baker \& Brown, 1984). To achieve reading comprehension, the readers need linguistic knowledge, the ability to understand or comprehend a text by applying both cognitive and metacognitive strategies, and an interactive relation between their prior knowledge and the information presented in the text. That is, reading comprehension occurs when skilled readers balance and coordinate many abilities in a very complex way to make comprehension proceed smoothly and more rapidly (Grabe \& Stoller, 2002).

Reading in the first language (L1) is different from reading in the second language (L2). Second languages differ from first languages in their way of creating meaning and in their writing systems, so L2 reading, which involves two languages, is more complex than L1 reading (Grabe \& Stoller, 2002). L2 reading comprehension is highly complex, dynamic, multi-componential, and multi-dimensional. L2 reading comprehension involves multiple interactions among readers. L2 readers perform the same functions as L1 readers, but their reading process could be slower and less successful (Phakiti, 2003). Reading proficiency in L2 does not develop as completely or as "easily" as it apparently does in one's first language since many components are involved. The reading process is not passive, but highly interactive, and reading comprehension does not occur automatically. Good readers are active readers who construct meaning through the integration of prior knowledge and new knowledge, and the use of a variety of strategies to control, regulate, and monitor their own reading comprehension (Grabe \& Stoller, 2002).

\section{Cognitive And Metacognitive Strategies And ReAding CompreHension}

According to Dole et al., (1991), reading comprehension is a constructive process by which readers use both cognitive and metacognitive strategies to build their understanding of a text. Cognitive strategies include the target language and have different methods such as summarizing and deductive reasoning, predicting, using organization, taking notes on the main points, using prior knowledge, and guessing meaning from the context (Oxford, 1990). Metacognitive strategies are actions that allow readers to control their own reading; in other words, they are strategies based on "thinking about thinking." That is, the readers know when and how to use these strategies and adapt them to suit their reading purposes. Metacognitive strategies involve planning, evaluating, and regulating one's own skills. These include such skills as determining the reading task, evaluating the predictions, focusing on important information, relating important information, ignoring unimportant new words, checking the effectiveness of guessing meaning, rereading relevant information when failure in understanding, and checking the effectiveness of achieving the whole reading task (Oxford, 1990).

Many researchers on reading strategy instruction According to Duffy (2002), Salataci and Akyel, (2002), state that metacognitive strategy training improves students' reading comprehension. It gives students a chance to plan before reading, control their reading process, organize their own rules, and evaluate themselves. Metacognitive strategy training shapes the students to become independent readers which is the goal of reading. Thus, in the reading classrooms, students should be trained to use metacognitive strategies to help them comprehend texts. The reciprocal teaching approach is one of the reading instruction methods which covers both cognitive and metacognitive strategies and helps students improve their reading comprehension and thus become independent readers. The teachers guide their students towards the right strategies to be used and instruct when and how to use them. Following this, the students will construct their own knowledge and make their own rules while reading texts. In the end, they will be able to apply these strategies and, from their application within cooperative groups, to perform reading tasks without any help from others.

\section{RECIPROCAL TEACHING AND ITS THEORETICAL FRAMEWORK}

The reciprocal teaching method is one of the effective approaches that teach learners to become responsible for their reading and employ metacognitive reading strategies over cognitive reading strategies (Cohen, 1998). The reciprocal teaching method has been recognized as a valuable teaching method by many researchers, reading teachers, and educators because it is a form of systematic training in strategies that help less efficient readers improve their reading comprehension and become independent readers (Palincsar \& Brown, 1984; Duffy, 2002; Soonthornmanee, 2002; Adunyarittigun \& Grant, 2005).

Theoretically, reciprocal teaching is based on Vygotsky's Zone of Proximal Development (1978) and the proleptic model of teaching (Wood, Bruner \& Ross, 1976, as cited in Manning \& Payne, 1996). According to Vygotsky's concept, children can develop their learning to reach a level of actual development by independently solving problems, and another level of potential development under adult guidance or expert scaffolding and in collaboration with more capable peers. For language teachers, it is necessary to provide the learners the tools that involve effective intervention and language learning strategies, and gradually remove these as the learners use them on their own. 
The aim of reciprocal teaching is to instruct students with particular strategies that they can apply to new texts. According to Palincsar and Brown (1984), reciprocal teaching is an instructional approach that can be best characterized by three main features: (a) the scaffolding and explicit instruction which a teacher uses and which include guided practice and modeling of comprehension-fostering strategies, (b) the four main reading strategies of predicting, generating questions, clarifying, and summarizing, and (c) social interaction which provides opportunities for learners to improve their cognitive, metacognitive and affective strategies and offers them chances to share ideas, increase confidence, and learn from their more capable friends. These three features help improve the students' ability to resolve comprehension difficulties, reach a higher level of thinking, build metacognition, and increase motivation. Consequently, students create new knowledge from what they internalize and develop their reading potential. From these three features, students promote their metacognitive awareness: planning before they read, comprehensionmonitoring or control of their own reading process while reading, and self-evaluation while reading and after reading, and if their self-evaluation points to any difficulties, effective readers fix those problems using the same process: planning, controlling, and evaluating.

The reciprocal teaching approach is one of the reading instruction methods which cover the necessary reading strategies: predicting, generating questions, clarifying, and summarizing. It helps students improve their reading comprehension, and thus become better readers. The aim of reciprocal teaching is to use discussion to improve students' reading comprehension, develop self-regulatory and monitoring skills, and achieve overall improvement in motivation (Allen, 2003). Its theoretical framework is based on three sociocultural theories namely, the zone of proximal development, proleptic teaching, and expert scaffolding (Brown \& Palincsar, 1984). The zone of proximal development refers to a learner's potential ability to learn with help from an expert or a more capable partner. It is Vygotsky (1978) who pointed out that all learners have two levels of thinking development: an actual development level and a potential development level. The actual development refers to the thinking level at which children are able to solve problems by themselves, and the potential development refers to the thinking level at which learners need help from an expert or a more capable partner. The zone of proximal development (ZPD) is the distance between the actual development and the potential development. Learners can push themselves from the actual development level to the potential level or learn beyond their actual development level with explicit scaffolding through social interaction until they internalize the strategies (Rosenshine \& Meister, 1994).

The second concept that forms the theoretical ground of the reciprocal teaching is called proleptic teaching and refers to procedures most often found during apprenticeship instruction in which a teacher shapes a student until he or she is ready to perform the task independently (Palincsar \& Brown, 1984). The significant feature of proleptic teaching is the transfer of responsibility from teacher to students. The teacher explains and models the process for solving problems, and while decreasing his or her role, transfers the responsibility of solving problems to the students (Rogoff \& Garner, 1984). The last concept is called expert scaffolding. The expert acts as a guide, shaping the learning efforts of the students and providing support for the learning until the students do not need it (Rosenshine \& Meister, 1994). Scaffolding procedures include limiting the tasks to make them manageable, motivating students, pointing out critical features, and demonstrating solutions to problems and explaining them to the students (Palincsar \& Brown, 1984). These procedures help students to learn how to perform a task, how to solve problems, and they support them in their attempt to learn until they can perform the task independently. According to Greenfield (1984), scaffolding teaching is adapted to the learners' current learning state; when the learners' skills are developed, the teacher's scaffolding is decreased, and if the text is difficult, greater assistance and feedback are given to the students in order to shape their understanding. The teacher acts as a facilitator after the students do not need much help. Scaffolding is eventually internalized and thus promotes the independent performance of reading skills.

These approaches provided the background theories to reciprocal teaching in which: (a) the teacher guides the students into the right use of the four key strategies and gives them a chance to practice them; (b) the teacher acting as an expert models the whole process of the reciprocal teaching approach for the students' benefit; (c) the students, supported by expert peers, work in cooperative groups as the teacher decreases support in order for the learners to develop independent reading competence (Adunyarittigun \& Grant, 2005).

\section{RELATED RESEARCH ON RECIPROCAL TEACHING}

In first language (L1) classrooms, research on reciprocal teaching and its effects on the reading abilities of different levels and groups of students has been extensively conducted: with primary and college students (Palincsar \& Brown, 1986; Palincsar \& David, 1990; Fillenworth, 1995), and with students with learning disabilities (Lederer, 2000). The results of these studies showed the positive effects of reciprocal teaching on the participants' reading comprehension abilities. Few studies have been conducted on reciprocal teaching. Adunyarittigun (2004), Ratanakul (1998), and Soonthornmanee (2002) studied the effects of reciprocal teaching on the reading comprehension of university students. The results showed that it had a positive effect on the participants' self-perception and reading performances. Konpan (2006) compared the effects of the reciprocal and communicative language teaching techniques on twelfth-grade students' reading comprehension. The results of this study revealed that the English reading comprehension of the reciprocal teaching group was significantly higher than that of the communicative language teaching group. The results 
of the studies on reciprocal teaching in Thailand have also showed that it has positive effects on students' reading comprehension.

\section{RELATIONSHIP BETWEEN RECIPROCAL TEACHING AND READING COMPREHENSION}

Palincsar and Brown (1984) explained that the purpose of reciprocal teaching is to promote the readers' ability to construct meaning from texts and facilitate the monitoring of their path to comprehension. It is based on a sociocultural method through which readers are modeled, explained, and guided in acquiring strategies within a social, supportive environment. The four main strategies of predicting, questioning, clarifying, and summarizing promote and enhance reading comprehension (Dole et al., 1991). Baker and Brown (1984) and Palincsar and Brown (1985) stated that those four main strategies were based on the following criteria: 1) the successful readers employ these strategies; 2) these strategies support both comprehension monitoring and comprehension fostering; 3) each strategy is applied when there is a problem in reading a text; 4) these strategies are regarded as metacognitive strategies. For these reasons, the readers who are taught through reciprocal teaching are more aware of their own thinking and reading process. They build effective reading plans such as setting a purpose to the reading, hypothesizing on what is being read, and drawing and testing hypotheses, interpretations, and predictions; they monitor and control their thinking process and check whether they understand; and they evaluate their own reading process, problem solving skills, and comprehension. Reciprocal teaching builds in the readers a metacognitive awareness of the active nature of reading, of task demands, and of selfregulating, in order to succeed in reading comprehension. It can be concluded that reciprocal teaching is a method providing vital reading strategy instruction that emphasizes on metacognitive awareness. Its goal is to improve readers' reading comprehension and to facilitate their becoming independent readers. It offers three features: scaffolding and direct instruction, practice of the four main strategies, and social interaction. It has been influenced by Vygotsky's developmental theory.

\section{CONCLUSION}

Based on the findings of this study, reciprocal teaching has a significantly positive effect on the English reading comprehension and metacognitive reading strategies of students. Reciprocal teaching enhances the reading ability of both the proficient and less proficient students. Students use the four key strategies and know what strategies to use, and when, why, and how to use each of them. They learn to predict, to generate questions, to identify the main idea of a paragraph, to clarify unclear words, phrases, or sentences, and to summarize their reading. The four key strategies help students overcome difficulties when reading texts as they plan and monitor their comprehension, and evaluate their planning and its outcome. For these reasons, it can be concluded that reciprocal teaching is a kind of reading instruction that facilitates the teaching of English reading comprehension. Reciprocal teaching is one of the reading strategy instructions that improve readers' metacognitive awareness. It leads students to think about their reading process, develop a plan of action, monitor their own reading in order to construct their own knowledge, and self-evaluate their reading process. They are able to become independent readers, which is the goal of teaching reading for EFL students. To sum up, reciprocal teaching provides effective metacognitive reading strategy instructions because it incorporates scaffolding and explicit teaching of the four main strategies, which creates an environment that facilitates productive information processing and reading comprehension. There are many important pedagogical implications for teachers, students, and educators in an EFL reading context. The most obvious pedagogical implication is that reciprocal teaching is one of the reading strategy instructions which enhances the student readers' reading comprehension and metacognitive awareness. In practice, these findings can be applied in English reading classrooms as follows:

1. To teach EFL students to use the four main reading strategies of reciprocal teaching, the teachers should provide appropriate explanations, explicit modeling, and on-going guidance. Reciprocal teaching requires the teachers to model explicitly and step by step the process and the use of the metacognitive strategies. The students have to know what the four key strategies are and when, why, and how to use them. They need a lot of time to practice each strategy and they need consistent practice of all of them. Time is also a concern when learning is involved. Students should be given enough time for each step. Since it is not always easy for them to accept and understand the four main reading strategies and the steps of reciprocal teaching, they need time to implement them all, to work in groups, to adjust to the leading role, even with the help of their friends, to get used to the steps of reciprocal teaching in general, and to use them automatically in their individual reading. The teachers could help the students to understand the process and procedure of reciprocal teaching by checking their understanding in their native language in order to make sure that they understand and know these process and procedure. This would help students to be confident to work on their own in cooperative groups.

2. The teachers should increase their students' responsibility by gradually decreasing their prompts and modeling, as their role changes to facilitators. They need to be flexible and attentive to help each student. If the learners have problems, the teachers should provide support and guidance to ensure success during the teaching activities.

3. To help students while they are working in cooperative groups, the teachers should circulate around the room and listen to the students' interactions. If the learners need help, they should be taught in their groups using appropriate mini-lessons. 
4. Teachers should choose materials based on their readers' ability, interest, and level of learning. The students might be given a shorter passage at the beginning and, with enough practice, they might be given a longer passage to help them feel more comfortable in their learning.

5. Reciprocal teaching can help students become more aware of metacognitive strategies through explicit instruction with social interaction, so they can learn gradually and control their own learning process. Reciprocal teaching has been shown to offer greater advantages over skill-based teaching. It is one of the successful metacognitive reading strategy instructions for EFL students. Thus, reciprocal teaching should be taken into consideration in order to adapt its implementation in the English reading class.

\section{ACKNOWLEDGEMENTS}

We thank Seyedeh Masoumeh Ahmadi, Alizadeh, and Babaei for their extensive and insightful discussions.

\section{REFERENCES}

[1] Adunyarittigun, D. (2004). The effects of reciprocal teaching procedure on Thai EFL students reading performance and selfperception as readers. Published doctoral dissertation, University of Maryland, United States of America.

[2] Adunyarittigun, D., \& Grant, R. (2005). Empowering students through reciprocal teaching. Thai TESOL BULLETIN, 18 (1), 1 13.

[3] Alderson, J.C. (2000). Assessing reading. Cambridge: Cambridge University Press

[4] Allen, S. (2003). An analytic comparison of three models of reading strategy instruction. IRAL, 41, 319-338.

[5] Baker. L., \& Brown, A.L. (1984). Metacognitive skill and reading. In R. Barr, M.L. Kamil \& P. Mosenthal (Eds.). Handbook of reading research (vol 2, pp. 353-364). NY: Longman.

[6] Carrell, P. L. (1989). Metacognitive awareness and second language reading. Modern Language Journal, 73, 120-133.

[7] Carter, C. (1997). Why reciprocal teaching? Educational Leadership, 54 (6), 64-71.

[8] Cohen, A.D. (1998). Strategies in learning and using a second language. Essex: Longman.

[9] Dole, J.A., Duffy, G.G., Roehler, L.R., \& Pearson, P.D. (1991). Moving from the old to the new: Research on reading comprehension instruction. Review of Educational Research, 61 (2), 239-264.

[10] Duffy, G. (2002). The case for direct explanation of strategies. In C. Block \& M. Pressley (Eds.). Comprehension instruction: Research-based best practices (pp. 28-41). New York: Guilford Press.

[11] Fillenworth, L. (1995). Using reciprocal teaching to help at-risk college freshmen study and read. Unpublished doctoral dissertation, University of Minnesota.

[12] Goodman, K. (1967). Reading: A psycholinguistic guessing game. Journal of the Reading Specialist, 6 (1), $126-135$.

[13] Grabe, W. (1991). Current developments in second language reading research. TESOL Quarterly, 25 (3), 375-406.

[14] Grabe, W., \& Stoller, F.L. (2002). Teaching and researching reading. Harlow: Pearson Education.

[15] Graves, M.F., Connie J., \& Bonnie G. (1998). Teaching reading in the 21st century. Boston, MA: Allyn and Bacon.

[16] Hacker, D.J., \& Tenent, A. (2002). Implementing Reciprocal teaching in the classroom: overcoming obstacles and making modifications. Journal Psychology, 94 (4), 699-718.

[17] Hart, E.R., \& Speece, D.L. (1998). Reciprocal teaching goes to college: Effects for postsecondary students at risk for academic failure. Journal of Educational Psychology, 90 (4), 670-681.

[18] Kern, R. (1989). Second language reading strategies instruction: Its effects on comprehension and word inference ability. Modern Language Journal, 73, 135-149.

[19] Klingner, J., \& Vaughn, S. (1996). Reciprocal teaching of reading comprehension strategies for students with learning disabilities who use English as a second language. Elementary School Journal, 96 (3), 275-293.

[20] Konpan, T. (2006). A comparison of reciprocal teaching technique and communicative teaching technique in developing Mattayom Suksa 4 Students'Reading Comprehension. Unpublished master dissertation, Srinakarinwirot University, Thailand.

[21] Lederer, J. (2000). Reciprocal teaching of social studies in inclusive elementary classrooms. Journal of Learning Disabilities, $33(1), 99-107$.

[22] Lysynchuck, L., Pressley, M., \& Vye, N. (1990). Reciprocal teaching improves standardized reading comprehension performance in poor comprehenders. Elementary School Journal, 90 (5), 469-484.

[23] Manning, H.B., \& Payne, D.B. (1996). Self talk for teacher and students. MA: Allyn \& Bacon.

[24] Mejang, A. (2004). The development of an English reading strategy instruction model based on collaborative learning principles for enhancing reading learning outcomes of university students. Unpublished doctoral dissertation, Chulalongkorn University, Thailand.

[25] Nunan, D. (1990). Second Language Teaching and Learning. Boston: Heinle \& Heinle Publisher.

[26] Nuttall, C. (1996). Teaching reading skills in a foreign language. Heinemann.

[27] Oxford, R. (1990). Language learning strategies: a synthesis of studies with implications for strategy training. Systems, 17 (2), 235-257.

[28] Palincsar, A.S., \& Brown, A.L. (1984). Reciprocal teaching of comprehension-fostering and comprehension-monitoring activities. Cognition and instruction, 1, 117-175.

[29] Palincsar, A.S., \& Brown, A.L. (1985). Reciprocal teaching: Activities to promote "reading with your mind." In T.L. Harris \& E.J. Cooper (Eds.). Reading, thinking, and concept development (pp.147-159). New York: The collage board.

[30] Palincsar, A.S., \& Brown, A.L. (1986). Interactive teaching to promote independent learning from text. The Reading teacher, 39 (8), 771-777.

[31] Palincsar, A.S., \& David, Y.M. (1990). Learning Dialogues for Comprehension and Knowledge Acquisition. Paper presented at the annual meeting of the Council for Exceptional Children, Toronto. 
[32] Paris, S.G., Cross, D.R., \& Lipson, M.Y. (1984). Informed strategies for learning: a program to improve children's reading awareness and comprehension. Journal of Educational Psychology, 76 (6), 1239-1252.

[33] Phakiti, A. (2003). A closer look at gender and strategy use in L2 reading. Language Learning, 53, 649-702.

[34] Pressley, M. Woloshyn, V., Lysynchuk, L., Martin, V., Wood, E., \& Willoughby, T. (1990). A primer of research on cognitive strategy instruction: The important issues and how to address them. Educational Psychology Review, 2, 1-58.

[35] Ratanakul, S. (1998). An experimental study of the use of the reciprocal teaching technique in teaching English reading comprehension. Unpublished master dissertation, Faculty of Graduate Studies, Mahidol University, Thailand.

[36] Rogoff, B., \& Gardner, W.P. (1984). Adult guidance of cognitive development. In B. Rogeff, \& J. Lave (Eds.). Everyday cognition: Its development in social context (pp. 134-157). NY: Cambridge University Press.

[37] Rosenshine, B., \& Meister, C. (1994). Reciprocal teaching: A review of the research. Review of Educational Research, 64 (4), 479-530.

[38] Royse, D. (2001). Teaching tips for college and university instructors: A practical guide. Boston: Allyn and Bacon.

[39] Rumelhart, D.E. (1977). Toward an interactive model of reading. In Dornic, S. (Ed.), Attention and Performance, V.1, 573-603. New York. Academic Press.

[40] Salataci, R., \& Akyel, A. (2002). Possible effects of strategy instruction on L1 and L2 reading. Reading in a Foreign Language. 14 (1), April. Retrieved April 2006, from http://www.proquest.umi.com.library.ecu.edu.au.

[41] Soonthornmanee, R. (2002). The effect of the reciprocal teaching approach on the reading comprehension of EFL students. RELC, 33 (2), 125-141.

[42] Stanovich, K. (1980). Concept of Developmental theories of reading skills: Cognitive resources, automaticity, and modularity. Developmental Review, 10, 72-100.

[43] Vygotsky, L.S. (1978). Mind in Society: The development of the higher psychological processes. Cambridge, MA: Harvard University Press.

[44] Wenden, A.L. (1999). An introduction to metacognitive knowledge and beliefs in language learning: beyond the basics. Systems, 27, 43-441.

[45] Wilson, J. (1988). Implications of learning strategy research and training: What is has to say to the practitioner. In C. Weinstein, E. Goetz, \& P. Alexander (Eds.), Learning and study strategies: Issues in assessment, instruction, and evaluation (pp. 323-331). San Diego, CA: Academic Press.

[46] Zabrucky, K., \& Ratner, H.H. (1992). Effects on reading ability on children's comprehension evaluation and regulation. Journal of Reading Behavior, 21 (1), 69-83.

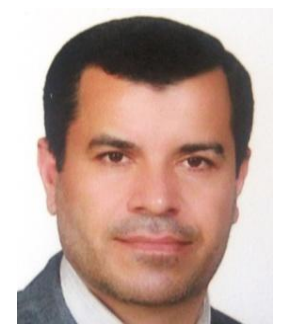

Mohammad Reza Ahmadi is a Ph.D. student of SLL at Universiti Sains Malaysia, Malaysia. He received his M.A. in English Language Teaching (ELT) from the Islamic Azad University of Garmsar, Iran. His main interests include reading skill and motivation.

Abbas Pourhosein Gilakjani is a Ph.D. student of TESOL at the Universiti Sains Malaysia, Malaysia. He is also a faculty member of English Translation Department at the Islamic University of Lahijan, Iran. He has taught English courses for over 12 years at 3 open universities in Guilan, Iran. 